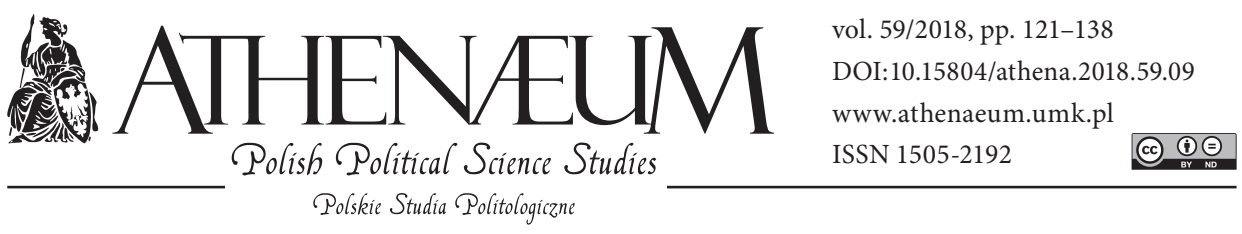

\title{
PUBLIC OPINION REGARDING THE POSTULATES OF THE LGBT COMMUNITY IN POLAND
}

\author{
OPINIA PUBLICZNA WOBEC POSTULATÓW ŚRODOWISKA \\ LGBT W POLSCE
}

Katarzyna Zawadzka*

\begin{abstract}
The article concerns public opinion regarding the postulates of sexual minorities. The basis for this discussion are public opinion polls conducted by the Public Opinion Research Centre. This allowed to present social tendencies regarding activities and postulates of the LGBT movement in Poland. The research polls span the period of time between 1998 and 2013. They concerned the following issues: opinions on homosexuality, social acceptance of homosexuality, attitude to same-sex marriage and civil partnerships, and gays' and lesbians' right to public demonstration. This discussion is founded on a theoretical overview regarding non-normativity.
\end{abstract}

Keywords: public opinion, LGBT, sexual minorities, civil partnerships
Artykuł podejmuje problem podejścia opinii publicznej do postulatów środowiska mniejszości seksualnych. Istotną część rozważań stanowią badania opinii publicznej opublikowane w komunikatach Centrum Badania Opinii Społecznej. Wskazano na tendencje, które zachodziły w społeczeństwie w odniesieniu do działalności i postulatów ruchu w Polsce. Badania opinii społecznej obejmują cezurę czasową od roku 1998 do roku 2013. Dotyczą następującej problematyki: opinii o homoseksualizmie, społecznej akceptacji homoseksualizmu, postaw wobec małżeństw homoseksualnych i związków partnerskich par homoseksualnych oraz prawa do publicznych demonstracji gejów i lesbijek. Przedstawiono także założenia teoretyczne obejmujące zagadnienia związane $\mathrm{z}$ nieheteronormatywnością.

Słowa kluczowe: opinia publiczna, LGBT, mniejszości seksualne, związki partnerskie

* Szczecin University, Faculty of Humanities. 


\section{INTRODUCTION}

The following article regards the issue of public opinion regarding the postulates of sexual minorities. An important part of this discussion is based on examination of public opinion polls published by the Public Opinion Research Centre (CBOS) in their reports.

The author addresses the question whether Polish society has significantly changed in the examined period when it comes to the activities and postulates of the LGBT movement in Poland.

The discussed opinion polls concern years 1998 to 2013. It regards the following issues: opinions on homosexuality, social acceptance of homosexuality, attitude to homosexual marriage and civil partnerships, and gays' and lesbians' right to public demonstration.

Theoretical assumptions, concerning non-normativity, are also presented below.

The objective of this article is to identify the postulates of the LGBT community in Poland and to discuss tendencies in Polish society regarding activities and issues important for sexual minorities in Poland.

\section{THE COMMUNITY OF SEXUAL MINORITIES}

An acronym LGBT is often used in discussion of sexual minorities. This abbreviation stands for lesbian, gay, bisexual and transsexual - as well as transgender (generally considered trans) people (Płeć i mniejszości seksualne - słownik, 2015). LGBT is defined as a so-called umbrella term, as this definition encompasses a very varied group, often included in one public discourse due to their similar social situation. This occurs also as a result of the fact that the aforementioned identities are perceived as linked by common interests and problems (Jabłońska \& Knut, 2012).

Bisexuality is sometimes defined as identifying a subject with both genders. The lines between femininity and masculinity are perceived as fluid and present inside each person (Lacroix, 2007). On the other hand, a definition of a transsexual person is made on the basis of a difference between the assigned gender and personal gender identity, where gender identity is understood as the one that is experienced internally, while the assigned gender is understood to be the one registered at birth (Lacroix, 2007). A difference is also noted between 
transgender and transsexual persons. The former, depending on their individual needs, express their gender identity using the attributes traditionally linked to the opposite gender (for instance, cosmetics, clothes, items, behaviours or manner of speaking). Such a person may decide to undergo a sex reassignment, in a legal form or in a form of a surgery, "in order to adjust their bodies to their experience of their own gender identity" (Lacroix, 2007). In other words, the difference between these terms concerns the need to modify one's appearance by means of permanent sex reassignment (Lacroix, 2007). This situation concerns transsexual people, whose gender identity is so distinct from their assigned gender that the aforementioned sex reassignment is necessary. In such a case, a decision about legal and medical sex reassignment is often made. Among transsexual people, one may distinguish transmen and transwomen. Transmen are the so-called F/M type, which signifies people of female sex, yet of masculine gender identity. Transwomen, on the other hand, are called the M/F type. They are those people who have male sex but feminine gender identity (Lacroix, 2007).

LGBT community is often described as sexual minority. What should be noted, however, is the fact that there is no universal definition of a minority. The problem appears when a distinction between those who belong to a political community and those who are excluded from it is made. In such a situation one becomes a political outsider. What is more, explanations defining minorities as a smaller part or number (especially in a political party and structure) assume that quantitative inferiority presupposes political one. That is not always the case, as in the end what is more important is an affiliation, not numbers (Preece,2007). LGBT community is perceived as a minority not in quantitative aspects, but in terms of rights available to general society.

As Xavier Lacroix has suggested, existential issues linked to homosexuality are additionally aggravated by social and psychological ostracism and rejection (Lacroix, 2007). According to this author, recognition of homosexuality may be understood in at least three ways: acceptance, social support, and public acknowledgment. Lacroix understands acceptance as an antithesis of exclusion and judgement. According to him, it is synonymous with acknowledging the lifestyle led by this community. Social support, on the other hand, regards support for solidarity and stable common life (Lacroix, 2007). Public acknowledgment is a form of lay sacrament, "a symbolic sanctification of a form of life, including a sexual bond" (Lacroix, 2007). Lacroix added that, from an ethical point of view, the postulates of these communities should be heard. Yet, he concluded that validation of the postulates of LGBT movement is faced with difficulties, 
as the ethics based on recognition of sexual minorities, which validates the first meaning and is not closed to the second one, does not automatically validate the third (Lacroix, 2007).

It should be stressed that attitudes towards homosexuality depend on the given culture, which in some countries is positive and accepting. The twentiethcentury specialist started to use the term "homosexual", using sexuality as a defining feature (Brannon, 2002). Don Clark states that words "heterosexual" and "homosexual" describe behaviours, not an identity. Yet, he adds, terms such as "gay" or "lesbian" have become commonly used in regard to identities, as a gay or a lesbian are people who are conscious of their homoerotic feelings and preferences (Clark, 1995). A question whether homosexuality is inborn or acquired is often asked in a social discourse. According to Clark (1995), a scholar of issues related to homosexuality, there is a choice concerning homosexual behaviour, but no such choice when it comes to homoerotic feelings.

Scholars examining issues regarding non-heterosexual communities must also face problems with definitions. It is perceived to be a pivotal issue, and so is that of linguistic context. At the same time, LGBT people are described as sensitive to specific nomenclature (Price, 2011). Therefore, "non-heterosexuality" is perceived as an appropriate term (Price, 2011). The issue of language and particular terminology might also be analysed from the perspective of what is noticeable, or what is available linguistically. This is problematised by the discrepancy between what is visible and what is expected, which shows how complicated the seemingly simple issues of definitions really are (Goddard \& Patterson, 2003).

As Artur Krasicki has emphasised, men loving representatives of their own sex existed in all cultures and historical periods. What changed throughout time has been social approach to these men. It should be added that usually this type of human sexuality has been stigmatised and rejected (Krasicki, 2006). Krasicki also pinpoints the aforementioned issues concerning definitions. According to him, there are problems with distinguishing homosexuality from transvestism, or even paedophilia. Homosexual community is usually presented in the social and academic discourse as "a secret margin; «difference» and «otherness» which needs sympathy and craves tolerance, understanding and respect" (Krasicki, 2006). On the basis of the results of his research, Krasicki states that Polish culture sees homosexuality as otherness which usually evokes negatives emotions. Negative attitude to non-heterosexual orientation is, according to Krasicki, rooted in a social conviction that homosexuals undermine one of the fundamental national values, that is, family (Krasicki, 2006). 
Recent years have brought a lot of changes in terms of legal solutions concerning sexual minorities. Most European states have introduced legal acts which are to counter discrimination of sexual orientation. However, introducing these changes does not mean that homosexuality is fully accepted (Pielas, 2014).

\section{THE POSTULATES OF POLISH LGBT COMMUNITY}

The postulates of the LGBT community have become an element of politics, increasingly gaining importance in the eyes of public opinion. The main postulates of the LGBT community include: legal recognition of civil partnerships, introducing a possibility to adopt children by non-heterosexual couples, legal regulations concerning gender identity, rejecting the so-called British Protocol in the Charter of Fundamental Rights of the European Union, introducing changes in educational and medical policy and counteracting verbal aggression (more often called hate speech) and physical one. However, introducing civil partnerships law is perceived as the main postulate of Polish LGBT groups.

Ultimately, achieving the goals mentioned above is related to ensuring a possibility to openly manifest one's sexuality in a public space, which is also one of the key objectives of the LGBT community. The activities undertaken by LGBT movement are addressed to general society, via national and local events. Activities aimed at non-heterosexual people, that are to consolidate the community, are also significant. Yet, above all, these activities are supposed to fulfil the postulates of the LGBT communities.

Values and political objectives characteristic of new social movements are, in the case of sexual minorities' community, reflected in "the variety of ideological approaches, types of strategies, and, at times, various perceptions of the situation of non-heterosexual people in Poland" (Wojnicka, 2011). Some actors/ actresses of Polish sexual minorities movement prefer more revolutionary and provocative actions, while "some support more «soft» and less confrontational methods" (Wojnicka, 2011). The latter group focuses their activities on creating a positive identity of LGBT people, concentrating on education and lobbying for legal changes, including anti-discriminatory laws and civil partnerships act (Wojnicka, 2011).

Prohibition of discrimination of whoever and for whatever reason is included in Polish constitution; however, in the context of LGBT community, this is perceived as a so-called "dead law" (Abramowicz \& Bratkiewicz, 2005). Currently, 
Polish law sees cohabiting homosexual couples as strangers who have no rights that are otherwise granted to married couples (Abramowicz \& Bratkiewicz, 2005). Poland also fails to respect the rights of homosexual couples who married in the European Union states where single-sex marriage is legally possible. This means that the moment such a couple arrives to Poland, they lose the rights they have abroad (Abramowicz \& Bratkiewicz, 2005).

The LGBT community argues that the rights of gays and lesbians are human rights, and a democratic political system presumes to respect those laws, thus protecting them from discrimination (Leszkowicz \& Kitliński, 2005). Sexual minorities in Poland also refer to dates and facts crucial for their objectives. In 1973, the American Psychiatric Association (APA) removed homosexuality from their Diagnostic and Statistical Manual of Mental Disorders. The World Health Organisation removed homosexuality from their list of ailments in 1992, while in 1998 APA issued a statement which condemned all attempts to cure homosexuality (Leszkowicz \& Kitliński, 2005).

According to LGBT movement, the debate about a possibility of fulfilling their postulates should be dominated by arguments concerning justice and equality. As sexual minorities state, legally acknowledging the single-sex relationships in Poland would be a realisation of human rights (Sypniewski \& Warkocki, 2004). As an important instrument in enforcing their human rights, activists in an organisation working for acknowledging these rights proclaimed a document in Yogyakarta, Indonesia, in 2006. A reconstruction of the international human right standards, applied to gender identity and sexual orientation, were included in this document (Wieruszewski, 2009). Martin Salm, the chairman of the Remembrance, Responsibility and Future Foundation, suggested that a Polish translation of the Yogyakarta Principles is necessary and useful as a point of reference and specific recommendations for civil initiatives and politicians (Salm, 2009). Salm added that in spite of a long democratic tradition, homosexual, bisexual and transsexual people in Poland cannot enjoy the same rights and lead the same peaceful lifestyle as other Polish citizens (Salm, 2009).

It should be emphasised that key international mechanisms in terms of human rights emphasise the responsibility of the states in ensuring effective protection from discrimination for their citizens. However, the flaws in actual realisation of this principle indicate that a consequent interpretation of international human rights and their implementation in terms of sexual orientation and gender identity are necessary (Wprowadzenie do Zasad Yogyakarty, 2009). 
Additionally, research concerning respecting the rights of the LGBT community, conducted in May 2015, showed that Poland was $33^{\text {rd }}$ country out of the 49 states included in the ranking. Poland was lower on that list than, for instance, Serbia, Bulgaria, Georgia, and Albania. The ranking was prepared by the European branch of the International Lesbian, Gay, Bisexual, Trans and Intersex Association ILGA. Its purpose was to show how close states are to full legal equality for LGBT community (Baliszewski, 2015).

\section{PUBLIC OPINION}

Already in late 1980s, the process of forming political awareness and public opinion was deemed to be a complicated one, as each organised activity is entangled in a complex social dialectics. It is accompanied by various forms of consciousness, which not only reflect social reality, but also create it (Kuśmierski, 1987).

Elisabeth Noelle-Neumann indicates that in most people, silence is perceived as fear of isolation. She defined public opinion as "views in a controversial matter, which may be voiced in public without the risk of isolation" (Noelle-Neumann, 2004). Yet, she supplements this definition and interpretation of public opinion with a description of the spiral of silence, which appears in a situation where opinions compete, and old opinions break down. According to Noelle-Neumann, the controversial element, as a condition of isolation, is evident when tradition, custom and established opinion are encroached (Noelle-Neumann, 2004).

For thousands of years, the controversies concerning gender roles, family models and sexual behaviour have been a source of the strongest social divisions. People have argued for centuries about cohabitation, polygamy or homosexuality. In contemporary world, limitation on a subject of discussion has been questioned by widely spread ideas of equality and human rights (Waltzer, 1999). It should be noted that "in some cases, it is conducive to consolidating tolerance, but in others it paves [...] the way for its opposite" (Waltzer, 1999). It can be assumed that social attitude towards LGBT community may be connected to social consciousness and the conditions of the social environment (Kuśmierski, 1987).

A type of social consciousness - political consciousness - includes practical and theoretical knowledge of a rational and irrational character. It both reflects and influences political phenomena and processes. It is conditioned by the past, but also includes actual and projective aspect (Kuśmierski, 1987). Stanisław 
Kuśmierski differentiates social consciousness from individual consciousness. The former, transferred to other people via cultural products and the consciousness of other members of a community, is in his opinion much richer than the individual consciousness. It is shaped in the process of communing with other people and it consists of mutual interactions of many subjects. Individual consciousness is shaped under the influence of society and as a result of adaptation of cultural models by the individual. Dynamism is its important ingredient, as it is a dynamic adaptation. An individual adapts to the environment as well as modifies it (Kuśmierski, 1987).

Generally available and disseminated opinions spread publicly, mainly in the mass media, and are considered to be the forms of expressing public opinion. Noelle-Neumann equated public opinion with "a compromise between a social agreement and the tendencies and beliefs of an individual" (Noelle-Neumann, 2004). One should remember, however, about a degree of controversy of the opinion or the level of vulnerability to the mass-media persuasion (Kuśmierski, 1987). The media identities of Polish gays are discussed by Samuel Nowak in his work Seksualny kapitał. Wyobrażone wspólnoty smaku i medialne tożsamości polskich gejów [Sexual Capital: Imagined Communities of Taste and Media Identities of Polish Gays]. The author indicates how people from LGBT community function in the media, for instance, in television shows or in the social action of the non-governmental organisation Anti-Homophobia Campaign called "Let Them See Us". Yet, he added that such representations have not translated into a positive social response to the LGBT community. According to Nowak, the reason for that lies in the fact that these minorities are usually associated with the adjective "sexual" that describes them, and with their suspect status in social hierarchy (Nowak, 2013).

Additionally, reflection on public opinion might also include the issue of submissiveness and impressionability, because people are forced to conformism in the fear of exclusion from society as a predicative institution (Noelle-Neumann, 2004). It also should not be forgotten that democracy is a system of procedures which in the end lead to the majority getting its own way. At the same time, democracy "must encompass institutionalised respect for the rights of political minorities in the attempt to become a majority" (Gibson, 2010). According to James L. Gibson, liberal democracy should make the means of questioning available to the political minorities; in other words, ensure the right to attempt to convince others about the validity of one's opinions (Gibson, 2010). This author also states that establishing institutions in majority governments is a simple task, 
while a much more difficult one is to ensure that the unpopular political minorities have the right to compete for political power (Gibson, 2010).

Analysing the attitude of the public opinion to the LGBT community, one should bear in mind that social opinions are inextricable from political opinions (Kuśmierski, 1987). Kuśmierski gave an example of political awareness which practically does not occur in a purely social form, but instead, socially and politically, has multilateral relations with ideology. According to this author, political and ideological awareness are inextricably linked to class and state categories. The choice of objectives, strategies, tactics, forms and methods of a specific political movement are reflected in political awareness. He states that all these are conditioned by ideology. Their proponents are political subjects which take part in political decisions or try to influence them (Kuśmierski, 1987).

The elections are undoubtedly important instruments in reflecting the public opinion, as they translate social preferences into legitimisation of power. Simultaneously, each election takes place in a difference social and economic context, which in each case might distribute social interests differently. It may be assumed that axiological issues prevail over the economic ones in times of stable economic situation and economic growth, making the latter a less important platform for political competition (Wojtasik, 2012). According to Noelle-Neumann, public opinion should concern publicly significant issues, and its carriers are the people who are ready and skilled to responsibly express their opinions publicly, in the name of the governed fulfilling the function of control and criticism of the government (Noelle-Neumann, 2004).

The objectives of the LGBT community are based on the assumption that a change in public opinion might be a means to an end, which in this case is the legal change. However, Noelle-Neumann suggests that it is the legal acts that change public opinion. According to this author, it may be stated that "by waiving or changing the rules one might trigger desired change in public opinion" (Noelle-Neumann, 2004). At the same time, she stresses that no rule can last for long if it is not rooted in a custom. She also mentions human fear of isolation and disapproval of the social environment. She is of an opinion that indirect signals are more effective when it comes to influencing behaviour than open, formal law (Noelle-Neumann, 2004). Noelle-Neumann criticises Walter Lippmann's definition of public opinion, as he omitted conformism in building or retaining an agreement and the aforementioned fear of isolation - an omission which she perceived as erroneous. Yet, she added that Lippmann stressed the most important element of public opinion: crystallisation of ideas and opinions in an 
emotionally-marked stereotype. Noelle-Neumann also invokes the fact that the word "stereotype" has been coined by Lippmann, who, in turn, adapted methods of stereotyping, which constitutes in casting a text in stiff moulds in order to reproduce it many times (Noelle-Neumann, 2004).

Important components of the process of shaping public opinion might include the following: the importance of the issue, forming private opinions into public ones, controversy of the issue, its influence on social matters, analogy to other people's opinions and the context of crowd psychology (Kuśmierski, 1987). It should be indicated at this point that public opinion is not unchangeable. It may undergo internal shifts, moving from one level of complication to another, and its "directionality and concreteness is linked to dependence of the opinion on social conditions" (Kuśmierski, 1987). Ireneusz Krzemiński states that in the perception of homosexuality a significant shift is noticeable, as the gay and lesbian movement has left the underground and dynamic organisations have emerged which can function in social space (Krzemiński, 2006).

It is even asserted social mechanisms of oppression and stigmatisation of homosexual people were instrumental in the emergence of a group awareness of LGBT people. Following constructivists, Bartłomiej Lis states that homophobia and the repressive system of homosexuality have led to shaping a specific homosexual identity in some members of LGBT community (Lis, 2008).

\section{LGBT COMMUNITY IN POLLS OF THE PUBLIC OPINION RESEARCH CENTRE}

It is worth noting that the research of the Public Opinion Research Centre (Centrum Badania Opinii Społecznej, CBOS) did not concern LGBT community as a whole; neither did it consider all postulates of this community. It only focused on social acceptance (or lack thereof), legal acknowledgment of civil relationships and same-sex marriage. The polls also related to the right to public expression of one's lifestyle and society's attitude to gay and lesbian persons fulfilling various social roles. At the same time, within the umbrella term "LGBT", the polls only focused on gays and lesbians.

As is shown by the CBOS report of 1994, sexual orientation seemed to matter to a large part of society. $40 \%$ of respondents indicated that they accept homosexuals as participants of social life. In case of $31 \%$ of respondents, there was no full acceptance. This part of respondents would not exclude homosexuals from 
local community but felt reserved towards them. $29 \%$ of respondents were characterised by the feeling of unfamiliarity and reserve towards non-heterosexual people. This group indicated that they do not accept homosexuals and do not want to have any personal relations with them (CBOS, 1994).

One should also mention at this point the results of the CBOS poll in 1988 and compare it to those of 2008. The CBOS report of 2008 indicated a stability and unchangeability of attitudes towards homosexuals. It suggested that in comparison to 1988 results, these opinions were identical. According to 2008 poll, $66 \%$ of respondents claimed that the Polish had a definitely hostile attitude to homosexuals, and only $1 \%$ of respondents saw friendly attitudes (CBOS, 2008). Yet, a change between those dates was noted in the context of the role of the state in the issues concerning homosexuality. In 1998, most respondents stated that the role of the state is to fight homosexuality, while 20 years later they suggested that the state should be neutral towards them (CBOS, 2008).

As the 2001 report on the poll concerning same-sex marriage showed, most Poles were against creating a legal possibility for homosexual couples to get married. According to the opinion of the vast majority of the Polish, homosexuality was perceived as deviation from the norm. Only one in twenty respondents stated that it is normal behaviour (CBOS, 2001). However, respondents were not unanimous when it comes to postulated treatment of non-heterosexual orientation. $47 \%$ of respondents indicated that they should be tolerated, while $41 \%$ did not accept tolerance (CBOS, 2001). Education was conducive to acceptance of legal regulations for same-sex marriage. Better educated respondents were more prone to accept such a possibility (CBOS, 2001). It was also shown that religiosity of respondents affected the opinions on same-sex marriage. $89 \%$ of respondents who attended religious rites several times a week and $78 \%$ of respondents who attended them once a week shared the Church's negative opinion in this matter. Among non-practicing Catholics, the opinions were divided. $45 \%$ of them accepted the idea of homosexuals getting married, while $48 \%$ expressed their disagreement (CBOS, 2001).

What should be noted at this point is the fact that the CBOS poll of 2012 showed that the Pope John Paul II's illness and death were particularly important in terms of Polish religiosity. Yet, the rise in religiosity was short-lived. As the 2012 poll indicated, most adult Poles - as many as 93\% - see themselves as Catholics. Simultaneously, the percentage of people identifying themselves as non-religious, atheists or agnostics rose from $2,1 \%$ to $4,2 \%$ (CBOS, 2012). CBOS researchers discovered that throughout a century both declarations of faith and 
attendance in religious practices have not significantly changed. Slight fluctuations in this aspect may be noted, in their opinions, depending on positive or negative events in the life of the Church, yet the general trend in Polish religiosity has stayed the same (CBOS, 2012).

The results of CBOS polls show that moral rules of Catholicism are perceived "as the best and sufficient by only one in five respondents" (CBOS, 2012). They also indicated that a significant selectivity and individuation of faith is evident, and Catholic morality is perceived as insufficient and is usually regarded selectively (CBOS, 2012). As transpires from CBOS research, identifying as a believer and regular attendance in religious practices do not translate into acceptance of many fundamental beliefs. Additionally, it does not have to exclude accepting opinions which are contrary to the teachings of the Catholic Church (CBOS, 2012). Yet, Polish religiosity remains to be exceptional in comparison to other European countries, and secularisation processes occur much slower than in Western Europe (CBOS, 2012).

Another LGBT postulate elaborated upon in the CBOS reports is one concerning the right to public demonstration of gays and lesbians. In 2005 poll, 58\% of respondents were of an opinion that organisations of gays and lesbians should not be allowed to organise public manifestations. 33\% of them said that sexual minorities should enjoy such a right (CBOS, 2005). What is more, opinions concerning this issue were linked to their place of residence and education. The better the education and the larger the town, the more often it was stated by the respondents that organisations of homosexual people should have the right to organise manifestations (CBOS, 2005).

In $2005,22 \%$ of respondents were ready to grant homosexuals the right to same-sex marriage. Yet, $72 \%$ of them were against it. Only $6 \%$ of respondents suggested that non-heterosexual people should have a right to adopt children. $90 \%$ of them rejected such a possibility (CBOS, 2005). $42 \%$ of respondents claimed that the law should ban homosexual couples from having sex. However, a similar group - 40\% - were of the opposite opinion (CBOS, 2005).

2010 poll showed that one in four Poles knows a person of homosexual orientation. They stated that declared acquaintance with gays and lesbians definitely affects the attitude to the presence of such people in public space, positively affecting the level of approval (CBOS, 2010). It was noted that this number rose from $15 \%$ in 2008 to $24 \%$ in 2010 . However, it was not entirely clear what this increase may have been induced by and whether this change could be a symptom 
of the society being more accustomed to non-heterosexuality, or of coming outs (revealing one's homosexuality) being more common (CBOS, 2010).

As 2011 CBOS research indicates, support for legal recognition of samesex civil partnerships are more often declared by relatively young people with higher education degree, living in larger cities, non-religious and declaring leftist political opinions. The strongest objection is voiced by pensioners, people attending religious practices several times a week and declaring right-wing political opinions (CBOS, 2011). It should be noted, however, that in terms of some of the rights the support was much stronger than a general acceptance of civil partnerships act (CBOS, 2011). CBOS researchers concluded that the model of a family in Poland has been changing, and that in turn leads to a shift in opinions concerning alternative forms of family life. It has been also noted that in comparison to 2010 poll, the objection to formalising homosexual relationships has significantly increased. This may be linked to, perhaps, a too general consideration of equalling the rights of people living in civil partnerships to those of married couples. The most decisive point in this respect was the issue that is most controversial in Polish society, that is, suggesting equal right to child adoption (CBOS, 2011).

Declaration of the respondents showed that the majority of adults, that is, $64 \%$, do not accept public manifestations of gays and lesbians. Events such as parades or festivals of sexual minorities seem to evoke negative social reactions. Moreover, respondents objected to ways in which sexual orientation is manifested, such as stylistics or indecent behaviour. In $2008,27 \%$ of respondents replied that in their opinion homosexuals should be allowed to organise public manifestations. $66 \%$ claimed the opposite. $25 \%$ of respondents suggested that same-sex couples should have the right to publicly manifest their lifestyle, while $69 \%$ were against it (CBOS, 2008). What should be added is the fact that the acceptance of gay and lesbian demonstrations was evident among better educated citizens of large cities who were younger than 45 (CBOS, 2010). The 2010 CBOS poll also considered the issue of professional segregation of non-heterosexual people. It showed that sexual orientation may be, in public imagination, a discriminating factor for an employee (CBOS, 2010). Two professions were most often named as ones to which access for non-heterosexual people should be limited: that of a teacher and a doctor. Some replies also mentioned priests, civil servants, politicians and uniformed professionals. The research indicated that answers suggesting that homosexual people should not perform people-oriented jobs were sporadic; yet, 
there were some very radical replies, according to which homosexuals should not have jobs at all (CBOS, 2010).

The CBOS polls of 2010 concerning social image of homosexuality showed a "stereotypical assumption that homosexuality - in contrast to heterosexuality - translates into, or uncontrollably affects some actions and activities which are not related to sexuality" (CBOS, 2010). The research paints a picture of social fears and anxieties, not about professional competence of homosexual people, but of propagating homosexual orientation. There were also elements of associating homosexuality with paedophilia (CBOS, 2010). Opinions treating homosexuality as aberration of the norm prevailed, although $63 \%$ of people claimed that it should be tolerated, while $23 \%$ claimed that it cannot be tolerated. Only $8 \%$ suggested that homosexuality is normal (CBOS, 2010).

As transpires from the CBOS research of 2011, the issue of legal recognition of heterosexual civil partnerships does not evoke general controversies. This is not true about homosexual ones: against such legal recognition are $65 \%$ of respondents, while $25 \%$ support them and $10 \%$ could not decide on either (CBOS, 2011).

The 2013 CBOS poll showed that $63 \%$ of respondents claimed that same-sex couples should not have a right to manifest their lifestyle. $68 \%$ of them did not accept legal recognition of non-heterosexual marriages, while $87 \%$ did not accept a possibility of child adoption for same-sex couples (CBOS, 2013). It should be noted that this poll was conducted after a political debate in Sejm, when bills had been proposed by Palikot Movement and Democratic Left Alliance, and by Civic Platform. These bills concerned one of the postulates of LGBT community, that is, legal recognition of civil partnerships for same-sex couples (CBOS, 2013). In CBOS report it has been stressed that this parliamentary debate concerned mostly ideological conflicts, where ethical aspects of homosexuality were taken into account. It has been indicated that during the debate less focus was given to the significant issues concerning civil partnerships and legal rights of people who were to enter them proposed in those bills (CBOS, 2013). It is worth noting that according to CBOS poll results of 2011, the support for legal recognition of civil partnerships of same-sex couples did not change, yet acceptance of informal same-sex relationships rose by $8 \%$ (CBOS, 2013). The CBOS research of 2013 indicated that $35 \%$ of respondents supported legal recognition of civil partnerships irrespective of the sex of the interested parties, 53\% accepted only heterosexual civil partnerships, while $11 \%$ were against any civil partnerships whatsoever (CBOS, 2013). 


\section{CONCLUSIONS}

Public opinion polls indicate that minority groups are not in the same situation. While attitudes to gays and lesbians are generally shifting towards more liberal ones, transsexual or bisexual persons are still seen as highly controversial (Stefaniak \& Bilewicz, 2014). It may be stated that some groups among minorities in Poland are more protected by the norms of political correctness than others. Offending homosexual people is more socially acceptable (Stefaniak \& Bilewicz, 2014).

Yet, personalisation is an important element. It is related to identifying a given postulate of LGBT community with a particular person. This may have both positive as well as negative effects. An abstract postulate of a minority might not be as important as when it is related to a known person or group. A community treated in a generalised and unified way as an anonymous group is more easily liable to be treated with hostility or indifference (Noelle-Neumann, 2004). It may be claimed that declared acquaintance with the community of sexual minorities is important in the context of declared attitude to some of the postulates of LGBT community. Declared acquaintance with gays and lesbians affects, for instance, one's attitude to the presence of such people in the public space, significantly increasing the level of acceptance.

As research conducted by the Public Opinion Research Centre shows, younger generation has different values than their ancestors, and changes in fundamental moral values are not a transient fashion or a whim. Such a conclusion is also evident in academic works. A link between growing secularization in post-industrial societies and shifts in moral values concerning sexuality is obvious. Beliefs and religious authorities are replaced by more secular and rational attitudes. Tolerance towards homosexuality and gay and lesbian rights are the central point of sexual liberalisation (Inglehart \& Norris, 2009).

In 2013, same-sex relationships were still a controversial issue for public opinion. Nevertheless, comparing the 2011 poll to the 2013 one, one may conclude that opinions concerning this issue underwent certain liberalisation. This fact is indicated by a gradual increase in tolerance toward homosexuality. At the same time, it is difficult to pinpoint what it actually entails, as generally neither legal recognition of civil partnerships and marriages of same-sex couple, nor even public manifestation of their lifestyles by gays and lesbians are socially accepted (CBOS, 2013). Not without reason voices are raised claiming that the supposed tolerance is rather limited. 
The oldest component of public opinion is perceived to be the moral element of consciousness. Already in antique societies there were opinion-forming bodies which expressed opinions on compliance of the issue with the moral code (Kuśmierski, 1987). As research indicates, it is the moral aspects that are most often touched upon by the antagonists of the postulates proposed by LGBT community. The most controversial ones of those postulates are legal registration of same-sex relationships and child adoption by non-heteronormative couples.

At the same time, one should not forget that non-heterosexual communities do not occur in a vacuum. They are parts of social and political environment. Therefore, the attitude towards the community of sexual minorities is related to the current political situation in Poland. This issue is complicated by the fact that crystallisation of public opinion on non-heterosexual community might be affected by the attitudes showed by political elites.

Yet, familiarising oneself with otherness and opening to LGBT postulates is an evolutionary process, which may be influenced by non-heterosexual community itself, via, for instance, informative actions in heterosexual communities.

LGBT people may see the chance for legal improvements in the shifts in Polish political scene, which, nevertheless, currently seems to be unfavourable to their postulates.

\section{REFERENCES:}

Abramowicz, M., \& Bratkiewicz, A. (2005). Jestem gejem. Jestem lesbijka. Komu moge o tym powiedzieć? Warszawa: Kampania Przeciw Homofobii.

Baliszewski, T. (2015). Polska dopiero na 33. miejscu w rankingu respektowania praw społeczności LGBT. Retrieved from: http://natemat.pl/142189,polska-nisko-wrankingu-rownosciowym-najlepiej-spolecznosci-lgbt-zyje-sie-w-wielkiej-brytanii.

Brannon, L. (2002). Psychologia rodzaju. Gdańsk: Gdańskie Wydawnictwo Psychologiczne.

CBOS (1994). Społeczna akceptacja homoseksualizmu. Komunikat z badań, $B S / 143 / 128 / 94$. Warszawa: Fundacja Centrum Badania Opinii Społecznej.

CBOS (2001). Postawy wobec małżeństw homoseksualistów. Komunikat $z$ badań, BS/49/2001. Warszawa: Fundacja Centrum Badania Opinii Społecznej.

CBOS (2005). Akceptacja praw dla gejów i lesbijek i społeczny dystans wobec nich. Komunikat $z$ badań, BS/127/2005. Warszawa: Fundacja Centrum Badania Opinii Społecznej.

CBOS (2005). Prawo do publicznych demonstracji gejów i lesbijek. Komunikat z badań, BS/193/2005. Warszawa: Fundacja Centrum Badania Opinii Społecznej. 
CBOS (2008). Prawa gejów i lesbijek. Komunikat z badań, BS/88/2008. Warszawa: Fundacja Centrum Badania Opinii Społecznej.

CBOS (2010). Postawy wobec gejów i lesbijek. Komunikat z badań, BS/95/2010. Warszawa: Fundacja Centrum Badania Opinii Społecznej.

CBOS (2011). Opinie o legalizacji związków partnerskich. Komunikat z badań, BS/76/2011. Warszawa: Fundacja Centrum Badania Opinii Społecznej.

CBOS (2012). Zmiany w zakresie wiary i religijności Polaków po śmierci Jana Pawła II. Komunikat $z$ badań, BS/49/2012. Warszawa: Fundacja Centrum Badania Opinii Społecznej.

CBOS (2013). Stosunek do praw gejów i lesbijek oraz zwiazków partnerskich. Komunikat $z$ badań, BS/24/2013. Warszawa: Fundacja Centrum Badania Opinii Społecznej.

Clark, D. (1995). Lesbijki i geje. Jak ich kochać. Warszawa: Wydawnictwo DaCapo.

Dalton, R.J., \& Klingemann, H.D. (2010). Zachowania polityczne. Vol. I. Warszawa: Wydawnictwo Naukowe PWN.

Goddard, A., \& Patterson, L.M. (2003). Language and Gender. Padstow, Cornwall: TJ International Ltd.

Inglehart, R., \& Norris, P. (2009). Wzbierająca fala. Warszawa: Państwowy Instytut Wydawniczy.

Jabłońska, Z., \& Knut, P. (eds.) (2012). Prawa osób LGBT w Polsce. Raport z badań nad wdrażaniem Zalecenia CM/Rec (2010)5 Komitetu Ministrów dla Państw Członkowskich $w$ zakresie środków zwalczania dyskryminacji opartej na orientacji seksualnej lub tożsamości płciowej. Warszawa: Kampania Przeciw Homofobii.

Krasicki, A. (2006). Homoseksualiści w Polsce. Studium środowiska (fragmenty). In: T. Basiuk, D. Ferens, \& T. Sikora (eds.), Parametry pożądania. Kultura odmieńców wobec homofobii (pp. 51-60). Kraków: Wydawnictwo Universitas.

Krzemiński, I. (ed.) (2006). Wolność, równość, odmienność. Nowe ruchy społeczne w Polsce poczatku XXI wieku. Warszawa: Wydawnictwa Akademickie i Profesjonalne.

Kuśmierski, S. (1987). Świadomość społeczna, opinia publiczna, propaganda. Warszawa: Wydawnictwo Naukowe PWN.

Lacroix, X. (2007). Miłość nie wystarczy. Homoseksualizm a prawo do zawierania małżeństw i do adopcji dzieci. Kraków: Wydawnictwo eSPe.

Leszkowicz, P., \& Kitliński, T. (2005). Miłość i demokracja. Rozważania o kwestii homoseksualnej w Polsce. Kraków: Wydawnictwo Aureus.

Lis, B. (2008). Czy homoseksualizm jest potrzebny socjologii? Socjologia odmienności (queer) w badaniach dekonstruujących męskość. In: E. Banaszak, \& P. Czajkowski (eds.), Moralne obrazy. Społeczne i socjologiczne (de)konstrukcje seksualności (p. 106). Wrocław: Wydawnictwo Uniwersytetu Wrocławskiego.

Noelle-Neumann, E. (2004). Spirala milczenia. Opinia publiczna - nasza skóra społeczna. Poznań: Wydawnictwo Zysk i S-ka.

Nowak, S. (2013). Seksualny kapitat. Wyobrażone wspólnoty smaku i medialne tożsamości polskich gejów. Kraków: Wydawnictwo Universitas. 
Pielas, J. (2014). Między homopresja a katonazizmem, czyli internetowe dyskusje o homoseksualizmie. Warszawa: Wydawnictwo SEDNO.

Płeć i mniejszości seksualne - słownik (2010, 2015, 2018). Retrieved from: http://ponton. org.pl/pl/strona/plec-i-mniejszosci-seksualne.

Preece, J.J. (2007). Prawa mniejszości. Warszawa: Wydawnictwo Sic.

Price, E. (2011). LGBT Sexualities in Social Care Research. London: School for Social Care Research, London School of Economics and Political Science.

Salm, M. (2009). "Równe prawa i spokojne życie" - osoby homoseksualne, biseksualne i transpłciowe w Polsce. In: K. Remin (ed.), Zasady Yogyakarty. Zasady stosowania międzynarodowego prawa praw człowieka $w$ stosunku do orientacji seksualnej oraz tożsamości płciowej (pp. 9-10). Warszawa: Kampania Przeciw Homofobii.

Stefaniak, A., \& Bilewicz, M. (2014). Polska: wyzwania. Mowa nienawiści jako studium przypadku. In: M. Mazur-Rafał, M. Szarota (eds.), Polska w ruchu. Eksperci i młodzi liderzy o wielokulturowości, transformacji i aktywizmie (pp. 75-88). Warszawa: Fundacja Humanity in Action Polska.

Sypniewski, Z., \& Warkocki, B. (eds.) (2004). Homofobia po polsku. Warszawa: Wydawnictwo Sic.

Walzer, M. (1999). O tolerancji. Warszawa: PIW.

Wieruszewski, R. (2009). Zasady Yogyakarty - geneza i znaczenie. In: K. Remin (ed.), Zasady Yogyakarty. Zasady stosowania międzynarodowego prawa praw człowieka $w$ stosunku do orientacji seksualnej oraz tożsamości płciowej (pp. 17-20). Warszawa: Kampania Przeciw Homofobii.

Wojnicka, K. (2011). Genderowe ruchy społeczne we współczesnej Polsce. In: K. Slany, J. Struzik, \& K. Wojnicka (eds.), Gender w społeczeństwie polskim (pp. 174-193). Kraków: Wydawnictwo Nomos.

Wojtasik, W. (2012). Funkcje wyborów w III Rzeczypospolitej. Teoria i praktyka. Katowice: Wydawnictwo Uniwersytetu Śląskiego.

Wprowadzenie do Zasad Yogyakarty (2009). In: K. Remin (ed.), Zasady Yogyakarty. Zasady stosowania międzynarodowego prawa praw człowieka $w$ stosunku do orientacji seksualnej oraz tożsamości płciowej (pp. 23-24). Warszawa: Kampania Przeciw Homofobii. 